\title{
How does Washback of PRETCO Influence College English Teaching
}

\author{
Xiaoling Zhang ${ }^{1, a}$ \\ ${ }^{1}$ Maoming Polytechnic, Maoming, Guangdong, 525000 \\ ${ }^{a}$ email,
}

\section{Keywords: Washback, PRETCO, College English Teaching}

\begin{abstract}
The Importance of tests on teaching is obvious in education system, and Madaus states that: "It is testing, not the "official" stated curriculum, that is increasingly determining what is taught, how it is taught' (as cited in Spratt, 2005, p.5). The present study examined the washback effect of a high-stakes examination, Practical English Test for College (PRETCO), and found that it exerts great influence on what to teach and how activities were conducted in Practical College English teaching classroom of Maoming Polytechnic. The teaching content is related to the test and the syllabus allots much time for the test preparation in Practical College English teaching.
\end{abstract}

\section{Introduction}

Practical English Test for Colleges (PRETCO), a large-scale national and standardized test, is designed to examine the English proficiency of students in Higher Vocational Colleges (HVCs) and Junior Colleges (JCs). PRETCO is for ensuring students of HVCs and JCs to reach the required English levels specified in Basic Requirements for the Course of English for HVCs and JCs (Higher Education Department of the National Ministry of Education, 2000). According to the differing English proficiency levels of students in HVCs and JCs, the Basic Requirements set two levels, Level A, which is more difficult, and Level B. In accordance with the Basic Requirements, the PRETCO consists of two levels, which are also called tests of level A and level B. The components of PRETCO are as follow: listening (15\%), grammar and vocabulary (15\%), reading comprehension (35\%), translation (20\%), and writing (15\%), among which objective items occupy 48\%, showing that the testing reliability is relatively high. PRETCO is a high-stakes test for our students. First of all, it is treated as the accurate assessment of their English language proficiency. The scores of the test have significant effect on their future career because when they graduate, they need the certificate to show their command of English. More importantly, in the previous years, students were denied the diploma, if they failed to pass the PRETCO. Finally, our English teaching is also measured by the students' pass rate of PRETCO.

With the hope that a better understanding of how the washback of PRETCO operates in my context can improve the teaching of Practical College English in my context, this study tries to investigate the washback of PRETCO on the English language teaching in Maoming Polytechnic. Also, because students of our college are only required to take level B, I only focus on the washback effect of PRETCO Level B. Here and after, when I say "PRETCO”, I mean PRETCO level B.

\section{Literature Review}

The word washback is very common in language teaching and testing literature, then, here comes the question: What is washback? There are a variety of answers though it is generally agreed that the impact of tests on teaching and learning is the washback of tests. In Hughes (1989) understanding of washback, he highlights the importance of promoting washback which is good for 
teaching and learning. Aldderson and Wall (1993) see washback as the "power of examination over what takes place in the classroom”. In answering the question, both Shohamy and Buck focus on the stakeholders of tests, the teacher and the students. Shohamy (as cited in Bailey, 1996, p. 258-259) defines washback as the "result of the strong authority of external testing and the major impact it has on the lives of test takers" while Buck (as cited in Bailey, 1996, p.258) describes it as the "natural tendency for both teachers and students to tailor their classroom activities to the demands of the test”. Biggs (as cited in Cheng, 1997, p. 34) uses the term 'washback' to refer to the fact that testing drives not only the curriculum, but teaching method and students' approach to learn.

Washback on What to Teach. Testing influences what to teach like what McEwen (as cited in Cheng and Curties, 2004, p.3) asserts "what is assessed becomes what is valued, which becomes what is taught”. Alderson and Hamp-Lyon's (1996) study of TOFEL preparation also support the washback effect of testing on what to teach and they point out that education measurement literature shows that "the higher the stakes of the test the stronger the urge to engage in specific test preparation practices" (p.282) instead of regular language teaching practices. To investigate the washback effect of PRETCO on "what to teach" in Maoming Polytechnic, this author focuses on teaching content, curriculum and teaching materials.

Washback on Teaching Content and Curriculum. In the field of wachback of testing, many researchers have done empirical studies and reported the washback effect of testing on teaching content and curriculum, including forward and backward directions.

In the forward direction of washback effect on teaching content and curriculum, there are Shohamy et al.'s (1996) and Cheng's (1997) empirical study reports. In Shohamy et al.'s (1996) longitudinal washback study of EFL in Israeli educational system between 1986 and 1991, they report that the relatively slight modification of EFL test results in better teaching content, the bringing of oral English practicing into classroom teaching, and more time allotment for oral English teaching. In Cheng's (1997) study of washback of the revised Hong Kong Certificate of Education Examination in English (HKCEE), she claims that the revised test brought about beneficial changes in teaching content and syllabus by saying.

Smith's (as cited in Alderson and Wall, 1993) and Wall and Alderson's (1993) empirical studies claim the negative washback of testing on teaching content and curriculum. In one of Smith's studies, "it was concluded that testing programs substantially reduced the time available for instruction and narrowed the curriculum and modes of instruction”(Alderson and Wall, 1993, p. 123). In Wall and Alderson's (1993) washback research into Sri Lankan O-Level Evaluation Project, they report that the "examination has had a demonstrable effect on the content of language lessons"(p.127). The demonstrable effect "was that the narrowing of the curriculum to those areas most likely to be tested” (Spratt, 2005, p.9).

Washback on Teaching Material. Testing may have great impact on teaching materials especially when the tests are high-stakes. Low-stakes tests exert little effects on teaching material and this claim is proved by Shohamy, et al.'s research into the Arabic Second Language (ASL) tests in Israel. ASL is attached little significance to and many students in the country even ignore the existence of it and it makes no impact on the teaching material during the period of Shohamy, et al.'s (1996) investigation.

Washback effect tests on teaching material can be beneficial for teaching in nature for the reason that it brings about a great deal of materials for teaching, namely, test books and courseware. Like Cheng (1997) claims that after the announcement of the revised HKCEE, nearly every school had changed their textbooks for the students. Tests, especially when they offer high stakes to candidates, generate various teaching materials. With the large amount of teaching material available in hand, 
teachers and students have more textbooks and other materials to select from.

However, it is very likely that, high-stakes examinations result in all kinds of exam-related materials or mock tests which are paralleled to the tests used in classroom teaching. The danger of using those exam-related materials or mock tests is that it turns teachers and students into 'textbook slaves' and 'exam slaves' with the teacher and students rely too heavily on exam-related text books and mock papers (Spratt, 2005).

\section{Research Question and Methods}

The purpose of this study was to investigate how PRETCO washback effect is on the English teaching Maoming Polytechnic, especially, on the teaching content and curriculum, teaching materials and teaching method.

The data collection of this study is based on the interview with four English teachers in the college. Interviews were conducted individually in Chinese and were audio-recorded. The audio-recording of the interviews was translated into English. The transcript and translation of the audio-recording was shown to the interviewees and consent by the interviewees for the accuracy of meaning.

For qualitative data analysis, the author uses a checking form to categorize the information points. In the checking form the category of information points are put in the left column and the related information is outlined in the right column. In the study, the participants are identified as Teacher A, B, C, and D for confidentiality.

\section{Findings of Washback of Pretco in My Context}

Washback on What to Teach in My Teaching Context. The interview data demonstrates that PRETCO level B test exerts great influence on what to teach in the Practical College English teaching classroom of Maoming Polytechnic.

Washback on Teaching Content and Curriculum in My Teaching Context. As regards the washback on teaching content and curriculum, the data analysis shows that the content for College English is narrowed down to focus on the items to be tested in PRETCO examination. Two of the four teachers interviewed mentioned that their teaching content is related to the test. Teacher A said "our English teaching is carried out focusing on PRETCO level B tests", and Teacher D pointed out that the "textbooks they used for College English teaching are compiled in accordance with PRETCO test syllabus”. It seems that PRETCO is considered as a very important factor in English teaching in Maoming Polytechnic. When asked whether they need to consider PRETCO in their English teaching, all the four teachers interviewed answered yes and said, "PRETCO is the most important factor in teaching" (Teacher A) and they "need to concern PRETCO when making teaching plan” (Teacher B). PRETCO preparation practice and test related instruction is the main teaching content in Practical College English classroom in Maoming Polytechnic.

Also the preparation for PRETCO is written into the teaching syllabus and teachers are required to allot considerably large amount of time for PRETCO preparation to ensure satisfying passing rates. Teacher A, B and C told that they spent at least one third or even a half of the College class hours of the second semester on test preparation. Also, the more weighted components in the PRETCO tests attract more attention from the teacher. In PRETCO, reading takes up 35\% while listening and writing occupy 15\% respectively and Teacher D's word shows the weighting of teaching according to the weighting of PRETCO components, "time allotment for listening is relatively less while for reading is relatively more. Writing is assigned and done after class and 
speaking takes place in the interactive activities within class”.

As PRETCO tests examine the practical use of English, which may be very important for the HVC students, whose future jobs need the practical use of English, we can see that PRETCO exerts positive influence on our teaching and show that direction of the Practical College English teaching in my context.

Washback on Teaching Materials in My Teaching Context. The washback effect of PRETCO level B tests on teaching material in Maoming Polytechnic may be that the PRETCO tests result in the constrained using of only test related material in the English teaching. In the general English teaching, teachers only follow the textbooks which are designed according to examination syllabus of PRETCO. All four teachers interviewed told that they mainly use the textbooks in Practical College English teaching. As Teacher A made it "our English classes generally follow the textbooks .......in general, English teaching is in line with the textbooks". However, one thing contradictory is that when asked how the students' learning performance is, Teacher A criticized the poor quality of teaching material, "I think that the main cause for students' unsatisfying study performance is our old and outdated teaching material, the content and design of which cannot catch steps with the development of our Social Economy". If it is really the case that the teaching material is not good in quality and leads to students' unsatisfying learning performance, the negative impact of the excessive dependence on teaching material in English teaching is even deeper.

\section{Conclusion}

Based on the finding of the study, the author concludes that PRETCO test, a large-scale and high-states test, exerts great influence on the teaching content and curriculum and teaching materials, whether it has washback effect on the teaching method is remained unknown.

Also, with the conclusion that washback effect of PRETCO tests exists and is bidirectional in nature, the author suggests some pedagogical implications to improve the quality of Practical College English instruction. General speaking, we should try our best to blunt the negative effect and make use of the forward moving direction of PRETCO tests. And the detailed implications are as followed.

First of all, it will be better for the English instructions if the administrators of the tests organization and the College could reduce a little bit of the stakes of the PRETCO. For example, abolishing the policy of denying students' diplomas if they fail the tests and stop using the passing rate to measure teachers' English teaching.

Second, we should make good use of the PRETCO positive washback effect of motivating students to learnt English. From the interviews of the four teachers we can see that they all have a positive attitude towards PRETCO because they believe that the tests serve as motivation and drive students to learn harder which in turn help their Practical College English teaching. So it is necessary for teachers to emphasize the good nature of the PRETCO, so as to motivate students to learn harder to improve their overall English proficiency and pass the tests.

\section{Reference}

[1] Alderson, J.C (2004). Foreword in L. Cheng, Y. Watanabe, and A. Crutis (eds), Washback in Language Testing: Research Context and Methods, Lawrence Erlbaum Associates, Mahwah, NJ, ix- $x$ ii.

[2] Alderson, J.C and Hamp-Lyons L.(1996). TOEFL preparation courses: a study of washback. Language Testing, 13, 280-297. 
[3] Alderson, J.C and Wall, D. (1993). Does washback exist? Applied Linguistics, 14 (2), 115-29.

[4] Andrews, S. (1995) Washback or washout? The relationship between esamination reform and curriculum innovation in R. Berry, V. Berry, and D. Nunan (eds), Bringing about change in language education. Hong Kong: Department of Curriculum Studies, University of Hong Kong, 67-81.

[5] Bailey, K. M (1996). Working for washback: a review of the washback concept in language testing. Language Testing. 13(3), 257-279.

[6] Cheng, L. Y. (1997). How does washback influence teaching? Implication for Hong Kong. Lnaguage and Education, 11, 38-54.

[7] Cheng, L. Y \& Curtis A. (2004). Washback or Backwash: A Review of the Impact of Testing on Teaching and Learning in L. Cheng, Y. Watanabe, and A. Crutis (eds), Washback in Language Testing: Research Context and Methods, Lawrence Erlbaum Associates, Mahwah, NJ, 3-17

[8] Higher Education Department of the National Ministry of Education, (2000). Basic Requirements for the Course of English for Higher Vocational Colleges and Junior Colleges. Higher Education Press.

[9] Hughes, A. (1989). Testing for language teachers. Cambridge: Cambridege University press.

[10] Qi, L. X. (2004). The Intended Washback Effect of the National Matriculation English Test in China: Intention and Reality. Foreign Language Teaching and Research Press.

[11] Spratt, M. (2005) Washback and the classroom: the implications for teaching and learning of studies of washback from exams. Language Teaching Research, 9 (1), 5-29.

[12] Shohamy, E. Donitsa-Schidt, S. and Ferman, I (1996). Test impact revisited: washback effect over time. Language Testing. 13, 298-317.

[13] Wall, D. and Alderson, J. C. (1993). Examining washback: the Sri Lankan Impact Study. Language Testing. 10, 41-69. 